\title{
Species of Pythium Associated with Seedling Root and Hypocotyl Disease on Common Bean (Phaseolus vulgaris) in Western Australia
}

Yu Pin Li, Ming Pei You, and Martin J. Barbetti, School of Plant Biology and The UWA Institute of Agriculture, Faculty of Science, The University of Western Australia, Crawley, WA, 6009, Australia

\begin{abstract}
Li, Y. P., You, M. P., and Barbetti, M. J. 2014. Species of Pythium associated with seedling root and hypocotyl disease on common bean (Phaseolus vulgaris) in Western Australia. Plant Dis. 98:1241-1247.

The occurrence and distribution of Pythium spp. were determined by collecting isolates of Pythium from common bean (Phaseolus vulgaris) plants showing root or hypocotyl disease symptoms from different areas of Western Australia in 2012. Eight different Pythium species (Pythium conidiophorum, $P$. diclinum, $P$. intermedium, $P$. irregulare, $P$. lutarium, $P$. mamillatum, $P$. pachycaule, and $P$. perplexum) were isolated and identified according to molecular sequences. $P$. irregulare was the most widespread Pythium sp. All species, except $P$. perplexum, were pathogenic to the hypocotyl and root of common bean. We believe this is the first report of $P$. intermedium as a pathogen on common bean worldwide. This is also the first report of $P$. conidiophorum, $P$. intermedium, $P$. lutarium, $P$. mamillatum, $P$. pachycaule, and $P$. dicli-

num as pathogens on common bean in Australia and the first report of $P$. irregulare as a pathogen on common bean in Western Australia. $P$. intermedium was the most pathogenic species, causing the most severe disease on 'Gourmet Delight' (percent root disease index [\%RDI] $75 \pm$ 2.9 and percent hypocotyl disease index [\%HDI] $59.2 \pm 3.2$ ) and 'Pioneer' (\%RDI $75 \pm 2.9$ and \%HDI $65.8 \pm 3.2$ ). That the relative susceptibility or resistance (the ability of a plant to reduce the extent of invasion by the pathogen) of a given bean variety to one Pythium sp. was, in general, similar across the other Pythium spp. was an important finding, because this opens up opportunities to utilize a single virulent isolate of one Pythium sp. to identify general resistance to a wider spectrum of Pythium spp.
\end{abstract}

Common bean (Phaseolus vulgaris L.) plays an important role in agronomic productivity, and is currently the third most important food legume crop in the world after soybean (Glycine max (L.) Merr.) and peanut (Arachis hypogaea L.) $(13,15)$. It not only improves soil nitrogen status for rotational crops but also has seed that contains a high proportion of human essential protein (approximately 22\%) and high levels of minerals (calcium, copper, iron, magnesium, manganese, and zinc; 12,27). In Australia in 2011, 98,000 t of dry common bean were harvested with a value of U.S.\$20 million and there is also substantial additional production as green common bean with a production of nearly 33,000 t (18).

Diseases, including soilborne diseases, constitute a serious challenge to common bean production $(1,27)$. Of the soilborne diseases, root rot is the major disease constraining production (33). Root rot often shows as a complex caused by several pathogenic fungi (e.g., Fusarium solani f. sp. phaseoli W.C. Snyder \& H.N. Hansen, Rhizoctonia solani Kühn, Pythium ultimum Trow, and Thielaviopsis basicola Berk. \& Broome [Ferraris]) and may also be associated with plant-parasitic nematodes (e.g., Pratylenchus spp.) individually or in any possible combination $(3,28)$. Among those pathogens, Pythium spp. have a worldwide distribution and a devastating impact across a range of different crops of economic importance (7). Damping-off and root rot disease caused by Pythium spp. are considered the main reason for declining quantity and quality of common bean, and remain the main constraint to common bean production worldwide $(3,36,37)$. For example, Pythium spp. are some of the most damaging species affecting common bean in East and Central Africa, where common bean is grown in intensive agricultural production systems (43). Similarly, in Rwanda, Pythium spp. are the most frequently isolated pathogen from diseased roots (39) and can cause yield losses there of up to

Corresponding author: M. J. Barbetti, E-mail: martin.barbetti@uwa.edu.au

Accepted for publication 24 March 2014.

http://dx.doi.org/10.1094/PDIS-12-13-1231-RE

(c) 2014 The American Phytopathological Society
$70 \%$ (34). Further, in African countries such as Burundi, the Democratic Republic of Congo, Kenya and Uganda, one or more Pythium spp. have been responsible for serious root disease epidemics in common bean $(31,34,43)$.

In eastern Australia, a number of different Pythium spp. have been found responsible for root disease. For example, $P$. intermedium de Bary has been found on parsnip (Pastinaca sativa L.) and parsley (Petroselinum crispum (Mill.) Nyman ex A.W. Hill) in southeastern Australia (35). Pythium perplexum H. Kouyeas \& Theoh. was associated with damping-off in messmate stringybark (Eucalyptus oblique H'hérit) and narrow-leaf peppermint (E. radiata Sieb. ex D.C.) (30), and P. diclinum Tokun. has been associated with root disease on subterranean clover (Trifolium subterraneum L.), the latter as reported in the Plant Health Australia (6).

In Western Australia, root or hypocotyl disease on common bean is widespread (M. J. Barbetti, data not published), and occurrences have been reported since 1921 (16,40). There, Pythium spp. are commonly associated with root disease or damping-off across a range of legumes. For example, several different Pythium spp., but particularly $P$. irregulare Buisman, widely occur on Lupinus spp. (40), and on pasture legumes such as Trifolium spp. $(8,10)$. Specifically, in relation to common bean, $P$. debaryanum R. Hesse and $P$. ultimum have been reported on this host in Western Australia $(16,40)$. However, because little was known about the role or importance of Pythium spp. in root or hypocotyl disease on common bean in Western Australia, a study was undertaken to determine the identity, role, pathogenicity, and virulence of Pythium spp. associated with root disease symptoms.

\section{Materials and Methods}

Survey and collection of isolates. A survey was conducted at eight locations across the greater Perth metropolitan region in Western Australia during the spring to autumn 2012 commonbean-growing season, specifically to identify oomycete pathogens associated with root or hypocotyl disease. Sizes of the sample sites ranged from 2 to 50 acres. All sites had a history of common bean production over at least the past decade. Five common bean plants were randomly picked and uprooted from each site, labeled, and put individually into polypropylene bags. Isolations were made on 
the day following sample collection. To isolate Pythium spp. from roots and hypocotyls of seedlings showing disease symptoms from the eight locations, diseased roots were washed under running tap water and then in distilled water, dried on sterilized filter paper, finely cut into pieces $2 \mathrm{~mm}$ in length, and cultured on cornmealbased 3P selective medium (4). Single-hyphal-tip cultures were then made by subculturing onto cornmeal agar (CMA) at $25^{\circ} \mathrm{C}$. These cultures were grouped into six different fungal or oomycete groups according to morphological characteristics; then, five to eight representative isolates from each group were subjected to molecular identification and phylogenetic study, as described below. The geographic location, species codes, and GenBank accession numbers of these single-hyphal-tipped isolates as used in this study are provided in Table 1 . Isolate WAC 714, previously isolated from common bean, was obtained from the Department of Agriculture and Food Western Australia Culture Collection. A historical $P$. irregulare isolate, C4953, that had been widely used in previous studies on pasture legumes (45), was also included as a comparison.

DNA extraction, amplification, and sequencing. To extract DNA, the mycelium of each of the 45 isolates was subcultured in liquid V8 medium and incubated in darkness at $25^{\circ} \mathrm{C}$ (32). Mycelium from 14-day-old cultures was harvested and DNA extracted following the procedure of Cenis (14). In brief, the mycelial mat was removed, blotted dry with filter paper, washed with Tris-EDTA (TE) buffer, and pelleted by centrifugation ( $5 \mathrm{~min}$ at 13,000 rpm), and the supernatant was decanted. After adding $300 \mu \mathrm{l}$ of extraction buffer (200 mM Tris-HCl [pH 8.5], $250 \mathrm{mM} \mathrm{NaCl,} 25 \mathrm{mM}$ EDTA, and $0.5 \%$ [wt $/ \mathrm{vol}]$ sodium dodecyl sulfate), the mycelia were crushed manually. Then, $150 \mu \mathrm{l}$ of $3 \mathrm{M}$ sodium acetate ( $\mathrm{pH}$ 5.2) was added, and tubes were maintained at $20^{\circ} \mathrm{C}$ for $10 \mathrm{~min}$. Subsequently, the supernatant was transferred to a fresh tube prior to adding an equal volume of isopropanol and centrifuged for $5 \mathrm{~min}$ at 13,000 rpm. After at least $5 \mathrm{~min}$ at ambient temperature (approximately $25^{\circ} \mathrm{C}$ ), the precipitated DNA was collected by centrifugation for $15 \mathrm{~min}$ at $13,000 \mathrm{rpm}$. The pellet was vacuum dried for several minutes after washing with $70 \%$ (wt/vol) ethanol and resus- pended in $50 \mu \mathrm{l}$ of TE buffer. The concentration and quality of the extracted DNA was determined by a NanoDrop 1000 Spectrophotometer (Thermo Scientific). The DNA was stored at $4^{\circ} \mathrm{C}$ until required. The primers internal transcribed spacer (ITS) 1 and ITS4 (42) were used to amplify part of the ITS1 and ITS2 regions and the intervening 5.8S rRNA gene. The polymerase chain reaction (PCR) reaction mixture consisted of $12.5 \mu \mathrm{l}$ of $2 \times$ GoTaq Green Master Mix (Promega, Australia), $0.4 \mu \mathrm{M}$ each primer, and $2 \mu \mathrm{l}$ of diluted genomic DNA and was made up to a final volume of $25 \mu \mathrm{l}$ with Milli-Q water. PCR was performed using a Kyratec Supercycler SC-200 under the following conditions: denaturation step of 5 min at $96^{\circ} \mathrm{C} ; 35$ cycles of $30 \mathrm{~s}$ at $96^{\circ} \mathrm{C}, 30 \mathrm{~s}$ at $55^{\circ} \mathrm{C}$, and $90 \mathrm{~s}$ at $72^{\circ} \mathrm{C}$; then a final elongation step at $72^{\circ} \mathrm{C}$ for $7 \mathrm{~min}$. PCR products were analyzed by electrophoresis on a $1 \%(\mathrm{wt} / \mathrm{vol})$ agarose gel containing ethidium bromide at $10 \mu \mathrm{g} / \mathrm{ml}$ and visualized under UV light. PCR products were then submitted to the Australian Genomic Research Facility in Perth for sequencing using the primers ITS1 and ITS4. The isolates were identified to the species level by conducting Basic Local Alignment Search Tool searches with the sequence data deposited in GenBank.

ITS sequencing and phylogenetic analysis. Consensus sequences were assembled using the DNASTAR Lasergene v7.1.0 software package. Then, consensus sequences were aligned with Clustal W and the alignments were manually refined. All gaps were treated as "missing" values. The alignments were then converted to Nexus format and imported into the PAUP (version 4.0b10) phylogenetic analysis program. A neighbor-joining tree was constructed with Jukes and Cantor correction method based on similarity analyses. The tree was generated with a bootstrap test of 1,000 replications. A bootstrap $>50 \%$ rule was used to separate isolates. All sequences were submitted to the GenBank database (accession numbers KF780539 to KF780564). Two isolates of $R$. solani (accession numbers JQ313811 and KF305079) were selected as the outgroup (bootstrap value $=100 \%$ ). The multi-alignment of the sequences have been deposited in TreeBASE (submission: 15060; http://purl.org/phylo/treebase/phylows/study/TB2: S15060).

Table 1. Details of Pythium spp. isolates obtained from common bean (Phaseolus vulgaris), including geographic location, isolate codes, species determinations, and GenBank accession numbers

\begin{tabular}{|c|c|c|c|c|c|}
\hline Latitude & Longitude & Soil type & Isolate code & Pythium spp. ${ }^{\mathbf{y}}$ & GenBank accession number \\
\hline \multirow[t]{3}{*}{$31.28400^{\circ}$} & $115.84393^{\circ}$ & Sand & UWA-L202 & Pythium lutarium & KF780544 \\
\hline & & & UWA-L207 & P. lutarium & KF780542 \\
\hline & & & UWA-L208 & P. intermedium & KF780558 \\
\hline \multirow{2}{*}{$31.28426^{\circ}$} & $115.83641^{\circ}$ & Sand & UWA-L103 & P. conidiophorum & KF780563 \\
\hline & & & UWA-L106 & P. mamillatum & KF780560 \\
\hline \multirow[t]{2}{*}{$31.33829^{\circ}$} & $115.56273^{\circ}$ & Sand & UWA-L302 & P. mamillatum & KF780559 \\
\hline & & & UWA-L303 & P. irregulare & KF780546 \\
\hline \multirow{3}{*}{$31.33844^{\circ}$} & $115.55453^{\circ}$ & Sand & UWA-L401 & P. lutarium & KF780543 \\
\hline & & & UWA-L405 & P. lutarium & KF780539 \\
\hline & & & UWA-L406 & P. irregulare & KF780564 \\
\hline \multirow[t]{9}{*}{$31.97287^{\circ}$} & $115.81769^{\circ}$ & Loam & UWA-6 R & P. diclinum & KF780541 \\
\hline & & & UWA-17B & P. conidiophorum & KF780551 \\
\hline & & & UWA-20B & P. conidiophorum & KF780550 \\
\hline & & & UWA-11B & $P$. perplexum & KF780554 \\
\hline & & & UWA-12B & P. perplexum & KF780553 \\
\hline & & & UWA-3B & P. intermedium & KF780557 \\
\hline & & & UWA-5B & P. intermedium & KF780556 \\
\hline & & & UWA-2B & P. irregulare & KF780561 \\
\hline & & & UWA-1B & P. irregulare & KF780562 \\
\hline \multirow[t]{2}{*}{$31.98578^{\circ}$} & $115.81494^{\circ}$ & Sandy loam & UWA-M3801 & P. intermedium & KF780555 \\
\hline & & & UWA-M2102 & P. irregulare & KF780547 \\
\hline \multirow[t]{4}{*}{$31.56702^{\circ}$} & $115.70706^{\circ}$ & Sandy loam & UWA-BF01 & P. lutarium & KF780540 \\
\hline & & & UWA-BF02 & P. pachycaule & KF780545 \\
\hline & & & UWA-BF03 & P. conidiophorum & KF780549 \\
\hline & & & UWA-BF04 & P. conidiophorum & KF780552 \\
\hline DAFWA $^{z}$ & DAFWA & Sand & WAC 714 & P. irregulare & KF780548 \\
\hline
\end{tabular}

${ }^{\text {y }}$ Five $P$. conidiophorum isolates were selected from three locations, one $P$. diclinum from one location, four $P$. intermedium from three locations, six $P$. irregulare from five locations, five $P$. lutarium from three locations, two $P$. mamillatum from two locations, one $P$. pachycaule from one location, and one $P$. perplexum isolate from one location.

${ }^{\mathrm{z}}$ DAFWA $=$ historical isolate WAC714 isolated from common bean and obtained from the Department of Agriculture and Food Western Australia Culture Collection, South Perth, Western Australia. 
Pathogenicity and virulence testing of eight Pythium spp. Tests for pathogenicity and for virulence were conducted. All 26 isolates were tested on a single commercial bean ('Pioneer'; Yates, Australia, code 18049) to determine pathogenicity. For the virulence tests, a single isolate randomly selected from each identified Pythium sp. was tested against two different commercial varieties ('Gourmet Delight' [Yates, Australia, code 17472] and Pioneer). Both the pathogenicity and the virulence experiments were fully repeated once.

Experimental conditions. For both the pathogenicity and virulence tests, seed was sown at a depth of $5 \mathrm{~cm}$ in free-draining pots (two seeds per 6-by-6-cm pot) filled with University of Western Australia potting mix (finely crushed pine bark/coco peat/sand at 2.5:1.0:1.5 [wt/wt]). The potting mix was pasteurized for $90 \mathrm{~min}$ at $65^{\circ} \mathrm{C}$ before use. All pots were maintained under controlled environment conditions at constant $18^{\circ} \mathrm{C}$ and with a 12 -h photoperiod. There were six replicates.

Inoculum preparation and plant inoculation. For each Pythium isolate, cultures were grown on CMA at room temperature for 5 days until mycelium had almost grown across the whole plate. Then, colonized CMA plugs $(1 \mathrm{by} 1 \mathrm{~cm})$ cut from the leading edge of the colonies were used to inoculate autoclaved millet seed to produce inoculum. Millet seed were prepared by first soaking in deionized water (in 250-ml flasks with approximately 150 $\mathrm{ml}$ of millet seed-water mixture per flask) overnight; then, excess water was drained and moist millet seed was autoclaved at $121^{\circ} \mathrm{C}$ for $20 \mathrm{~min}$, once on each of three consecutive days. The inoculated millet seed plus, for each Pythium isolate, colonized agar pieces were then incubated at $25^{\circ} \mathrm{C}$ under darkness for 2 weeks. Flasks were shaken by hand once a day in the first 2 days to ensure that CMA plugs were evenly distributed in the millet. After 2 weeks of incubation, millet seed inoculum was mixed with pasteurized potting mix for each different Pythium sp. isolate at a ratio of $0.5 \%$ (wt/wt) (45) in pots before sowing common bean seed. At the time of inoculation of the potting medium, quality of the inoculum was checked by plating approximately 15 colonized millet seeds onto CMA plates to confirm that each Pythium sp. was the sole organism present on the seed. In each experiment, $200 \mathrm{~g}$ of noninoculated or inoculated soil was used to fill each pot, two seeds per pot were sown at a depth of $5 \mathrm{~cm}$, and pots were then watered daily to free draining. Fully replicated uninoculated control pots were used as a comparison control.

Disease and shoot dry weight assessments. For the pathogenicity tests, disease was simply recorded as presence or absence of any visual disease symptom on roots or hypocotyls. For virulence tests, disease assessments of emerged seedlings were conducted 5 weeks after sowing. Seedlings were cut at the level of the soil surface and roots and shoots separated. Roots were washed thoroughly with pressurized tap water. Then, the severity of root and hypocotyl disease on surviving plants was assessed using a visual disease assessment scale modified from Abawi and PastorCarrales (2). Root disease severity was measured as follows: score of $0=$ no root disease symptoms, $1=<20 \%$ roots showing obvious lesions, 2 = root system showing a moderate level of general decay, $3=$ root system showing extensive general decay and with an obvious reduction in overall root materials (but $<50 \%$ of root system missing), and $4=$ the root system showing very severe levels of general decay associated with extensive reduction in overall roots ( $>50 \%$ root system missing) or where the plant has died. Hypocotyl disease severity was measured as follows: score of $0=$ no hypocotyl disease symptoms, $1=$ maximum $10 \%$ of hypocotyls with lesions, $2=10$ to $\leq 25 \%$ of hypocotyls with lesions, $3=>25$ to $\leq 50 \%$ of hypocotyls with lesions, $4=>50$ to $\leq 75 \%$ of hypocotyls with lesions, and $5=>75 \%$ of hypocotyls with lesions or the plant has died. Shoots and roots for each surviving plant were separately oven dried at $60^{\circ} \mathrm{C}$ for 3 days; then, dry weights were recorded.

Statistical analyses. All experiments were arranged in a completely randomized design. For the virulence test, for disease score data on a range of 0 to 4 (roots) or 0 to 5 (hypocotyl), a percent disease index (\%DI) was calculated using the formula of McKin- ney (25): \%DI $=\{[(a \times 0)+(b \times 1)+(c \times 2)+(d \times 3)+(e \times 4)+$ $(f \times 5)] /[(a+b+c+d+e+f) \times g]\} \times 100$, where $a, b, c, d, e$, and $f$ represent the number of plants with disease scores of $0,1,2,3$, and 4 (root disease and hypocotyl) and, with the addition of score 5 for hypocotyl disease only, $g$ represents the highest rating of root disease or hypocotyl disease. Root disease severity, hypocotyl disease severity, shoot dry weight, and root dry weight were analyzed separately for the virulence test using analysis of variance with GenStat, 15th ed. (Lawes Agricultural Trust, Hemel, Hempstead, UK). Fisher's least significant differences $(P<0.05)$ were used to compare genotype reactions to the different Pythium isolates. The relationship between the initial virulence test experiment and its repeat experiment were assessed by using one-sided paired $t$ tests in GenStat and by regression analyses across each disease assessment parameter. Further, the Brown-Forsythe test was also conducted to determine whether variances between data sets were homogeneous. These tests showed no difference between this pairing of repeated experiment $(P>0.05)$; therefore, data from each duplicate virulence test experiment was consolidated and reanalyzed together as a single data set.

\section{Results}

Identification and distribution of Pythium spp. Pythium root disease was readily observed across the areas sampled in this study. Of the 128 isolates cultured, from the 45 isolates subsampled, purified, and ITS region sequenced, 26 isolates belonged to eight different Pythium spp. These were $P$. conidiophorum Jokl, $P$. diclinum, $P$. intermedium, $P$. irregulare, $P$. lutarium Ali-Shtayeh, $P$. mamillatum Meurs, $P$. pachycaule Ali-Shtayeh, and $P$. perplexum (Table 1). Of these, $P$. irregulare was the most commonly isolated species. In contrast, other Pythium spp. such as $P$. mamillatum, $P$. perplexum, $P$. pachycaule, and $P$. diclinum were only isolated from a single location. Except for $P$. irregulare, none of these Pythium spp. had been previously documented to be responsible for bean root or hypocotyl disease anywhere in Australia. Further, we believe this is the first report of $P$. intermedium as a pathogen on common bean worldwide.

ITS sequencing and phylogenetic analysis. The phylogenetic tree showed that all isolates grouped into two main clades (namely, A and B), with a bootstrap value of $99 \%$ (Fig. 1). In clade A, there were two subclades (namely, I and II). P. conidiophorum isolates were distributed within subclade I. P. diclinum, P. pachycaule, and $P$. lutarium were within subclade II.

There were four subclades (namely, III, IV, V, and VI) within clade B, where each subclade included one species as follows: $P$. perplexum in subclade III, $P$. intermedium in subclade IV, $P$. mamillatum in subclade V, and P. irregulare in subclade VI.

Pathogenicity test. With the exception of $P$. perplexum, all Pythium isolates tested caused root or hypocotyl disease to seedlings of Pioneer. No symptoms of root rot or hypocotyl disease were found on uninoculated control plants, nor were any symptoms at all observed on the plants inoculated with $P$. perplexum. Koch's postulates were fulfilled: all eight pathogenic Pythium spp. were successfully reisolated from common bean diseased root or hypocotyl tissues and displayed similar root or hypocotyl symptoms as observed in the field.

Virulence test. When a single isolate was randomly selected from each identified Pythium sp. and tested on two different commercial varieties (Gourmet Delight and Pioneer), the results were as follows.

Disease severity. In terms of root disease severity, there was a significant effect of Pythium spp. $(P<0.001)$ and common bean variety $(P<0.001)$ and a significant interaction between the two $(P$ $=0.002$ ) $($ Table 2$)$. In general, Pioneer (percent root disease index [\%RDI] $52.1 \pm 1.0$ ) had more severe root disease than Gourmet Delight (\%RDI $43.6 \pm 1.0$ ) (Table 3). P. intermedium caused the most severe disease on both Gourmet Delight (\%RDI $75.0 \pm 2.9$ ) and Pioneer (\%RDI $75.0 \pm 2.9$ ), whereas $P$. irregulare caused the least severe disease on Gourmet Delight (\%RDI $40.1 \pm 2.9)$ and Pioneer $(\%$ RDI $57.3 \pm 2.9)$. There was no significant difference of 
root disease severity observed between the plants inoculated with $P$. conidiophorum or with $P$. lutarium and, similarly, there was also no significant difference in root disease severity between the historical $P$. irregulare isolate $\mathrm{C} 4953$ and with $P$. mamillatum on both varieties tested. In terms of hypocotyl disease severity, there was a significant effect of Pythium spp. $(P<0.001)$ and variety $(P<$ $0.001)$ and a significant interaction between the two $(P=0.002)$ (Table 2). In general, Pioneer (percent hypocotyl disease index [\%HDI] $44.5 \pm 1.1$ ) had more severe hypocotyl disease than Gourmet Delight (\%HDI $36.8 \pm 1.1$ ) (Table 3). P. intermedium caused the most severe disease on both Gourmet Delight (\%HDI $59.2 \pm$ 3.2) and Pioneer (\%HDI $65.8 \pm 3.2$ ). On Gourmet Delight, there was no significant difference between $P$. intermedium, $P$. irregulare historical isolate C4953, and P. mamillatum in terms of hypocotyl disease severity; also, no significant difference was found between $P$. irregulare, $P$. conidiophorum, and $P$. lutarium. On Pioneer, although $P$. intermedium caused the most severe disease, there was no significant difference in disease severity between $P$. intermedium and the P. irregulare historical isolate C4953.

Shoot dry weight. Significant differences were recorded between Pythium spp. $(P<0.001)$ and variety $(P<0.001)$ and a significant interaction between the two $(P=0.003)$ (Table 2$)$. In general, Pioneer $(496 \pm 12.2 \mathrm{mg})$ had greater shoot dry weight than Gourmet Delight (219 $\pm 12.2 \mathrm{mg}$ ) (Table 3). Plants inoculated with historical isolate P. irregulare C4953 had the least shoot dry weight on both Gourmet Delight $(142.0 \pm 34.5 \mathrm{mg})$ and Pioneer $(335.0 \pm 34.5$

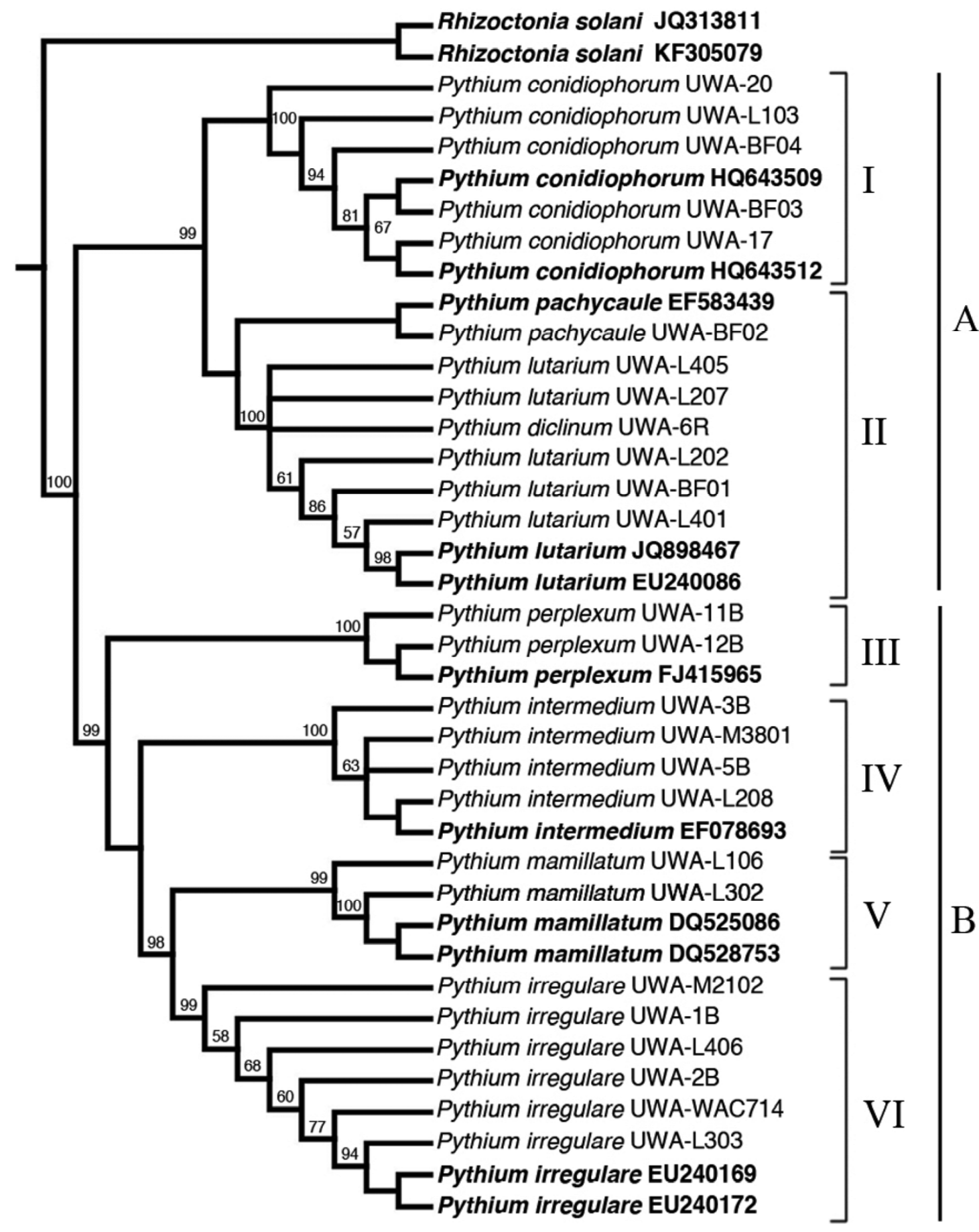

Fig. 1. Neighbor-joining tree of the internal transcribed spacer sequence data constructed with Jukes and Cantor correction method for Pythium spp. isolates obtained from common bean (Phaseolus vulgaris). Bootstrap values of 1,000 replications are represented for the major branch. Two isolates of Rhizoctonia solani were used as an outgroup. 
$\mathrm{mg}$ ). On Gourmet Delight, only historical isolate P. irregulare C4953 and $P$. irregulare caused significant shoot dry weight reduction. Compared with uninoculated plants, there was no significant difference in terms of shoot dry weight whether plants were inoculated with $P$. conidiophorum, $P$. intermedium, $P$. lutarium, $P$. mamillatum, or $P$. perplexum. In Pioneer, all Pythium spp. caused significant reduction of shoot dry weight compared with uninoculated plants, except for $P$. perplexum. However, there was no significant difference between $P$. irregulare, $P$. intermedium, $P$. lutarium, and $P$. mamillatum in terms of shoot dry weight.

Root dry weight. In relation to root dry weight, there was a significant effect of Pythium spp. $(P<0.001)$ and variety $(P<0.001)$ (Table 2). Plants inoculated with historical isolate $P$. irregulare C4953 had the smallest root dry weight compared with uninoculated plants. Pioneer $(224 \pm 5.4 \mathrm{mg})$ had greater root dry weight than Gourmet Delight (139 $\pm 5.4 \mathrm{mg})$ (Table 3).

\section{Discussion}

Of the eight Pythium spp. identified in our study, some (such as $P$. lutarium, $P$. conidiophorum, $P$. pachycaule, and $P$. diclinum) had previously been reported as soilborne pathogens of common bean in other countries $(5,17,20,29,32,44,47)$. However, none of these eight species have previously been documented as responsible for bean root or hypocotyl disease in Western Australia or even in Australia, except for $P$. irregulare, which had been noted as a pathogen on common bean in New South Wales and Queensland (6).

Based on the data from both our pathogenicity and virulence tests, all the Pythium spp. isolated in Western Australia were pathogenic on common bean, except $P$. perplexum. There were no disease symptoms on the plants inoculated with $P$. perplexum, nor were there any significant reductions in shoot or root dry weights from $P$. perplexum, which was not able to be reisolated from common bean following the inoculations. It is clear that the isolates we obtained of this species were not pathogenic to common bean. Some Pythium spp. clearly caused less root or hypocotyl disease than others.

The virulence tests showed that different common bean varieties responded differently to a given Pythium sp., because the level of disease severity was different depending upon the variety inoculated. However, there was a clear trend for each variety to maintain its relative expression of resistance (23) (i.e., the ability of a plant to reduce the extent of invasion by the pathogen) or susceptibility on both roots and hypocotyls across the different Pythium spp. used in our study. In a similar way, when Nzungize et al. (32) conducted an investigation of the disease severities caused by $P$. arrhenomanes Drechsler, $P$. chamaihyphon Sideris, $P$. conidiophorum, P. cucurbitacearum S. Takim., $P$. diclinum, $P$. dissotocum Drechsler, $P$. folliculosum B. Paul, $P$. indigoferae E.J. Bulter, $P$. macrosporum Vaartaja \& Plaäts-Nit, $P$. pachycaule, $P$. rostratifingens De Cork \& Lévesque, $P$. rostratum E.J. Bulter, $P$. spinosum Sawada, P. torulosum Coker \& P. Patt., P. ultimum, and $P$. vexans de Bary across 11 common bean varieties, they also found that the resistance or susceptibility of a given bean variety to one Pythium sp. was similar across all the other Pythium spp. This is an important finding, because this opens up opportunities to utilize a single virulent isolate of one Pythium sp. to identify general resistance to a wider spectrum of Pythium spp.

In our study, $P$. irregulare was shown to be the most widespread Pythium sp. in the greater metropolitan region of Western Australia, constituting 6 of the 26 isolates obtained from the five locations surveyed, and it caused significant reduction of both shoot and root dry weights. These results are in agreement with others previously reported across much more extensive regions across the whole of the southwest of Western Australia, where $P$. irregulare was not only the most common Pythium sp. on legumes showing root disease (9-11) but also was a pathogen causing significant yield loss on a number of different legume hosts; for example, annual Medicago spp. (46) and annual Trifolium spp. (10).

Prior to this study, $P$. irregulare has been reported elsewhere in Australia on common bean in New South Wales and Queensland. In Western Australia, only $P$. debaryanum and $P$ ultimum had previously been reported from common bean (40). None of the Pythium spp. identified from our study had been previously documented to be a common bean pathogen in Western Australia. However, historically, $P$. irregulare had been reported as the most com-

Table 2. Statistical main effects and interactions showing the effect of different Pythium spp. on the root disease severity index, the hypocotyl disease index, shoot dry weight, and root dry weight when tested on two varieties of common bean (Phaseolus vulgaris) ${ }^{\mathrm{y}}$

\begin{tabular}{|c|c|c|c|c|c|c|c|c|}
\hline \multirow[b]{2}{*}{ Main effects } & \multicolumn{2}{|c|}{ Root disease index } & \multicolumn{2}{|c|}{ Hypocotyl disease index } & \multicolumn{2}{|c|}{ Shoot dry weight } & \multicolumn{2}{|c|}{ Root dry weight } \\
\hline & $P$ value & LSD & $P$ value & LSD & $P$ value & LSD & $P$ value & LSD \\
\hline Pythium spp. & $<0.001$ & 5.8 & $<0.001$ & 6.3 & $<0.001$ & 68.1 & $<0.001$ & 30.3 \\
\hline Variety ${ }^{\mathrm{z}}$ & $<0.001$ & 2.9 & $<0.001$ & 3.2 & $<0.001$ & 34.0 & $<0.001$ & 15.0 \\
\hline Pythium spp.-variety & 0.002 & 8.2 & 0.002 & 8.9 & 0.003 & 96.3 & n.s. & $\ldots$ \\
\hline
\end{tabular}

${ }^{y}$ Each experiment was arranged in a completely randomized design and repeated once with six replicate pots per treatment combination (two bean seeds/pot) planted; means within a column followed by the same letter do not differ significantly based on Fisher's least significant difference (LSD) at $P=0.05$; n.s. $=$ not significant. Results were pooled over the repeats of the experiment as described in the main text.

${ }^{\mathrm{z}}$ Two bean varieties were used: 'Gourmet Delight' and 'Pioneer', as described in the main text.

Table 3. Effect of different Pythium spp. on the root disease severity index, hypocotyl disease index, shoot dry weight, and root dry weight when tested on two varieties of common bean (Phaseolus vulgaris), 'Gourmet Delight' (GD) and 'Pioneer' (PN) ${ }^{\mathrm{z}}$

\begin{tabular}{|c|c|c|c|c|c|c|c|c|}
\hline \multirow[b]{3}{*}{ Species } & \multicolumn{8}{|c|}{ Common bean variety } \\
\hline & \multicolumn{2}{|c|}{ Root disease index } & \multicolumn{2}{|c|}{ Hypocotyl disease index } & \multicolumn{2}{|c|}{ Shoot dry weight (mg) } & \multicolumn{2}{|c|}{ Root dry weight (mg) } \\
\hline & GD & PN & GD & PN & GD & PN & GD & PN \\
\hline Control & 0 & 0 & 0 & 0 & $276 \mathrm{c}$ & $668 \mathrm{~d}$ & $170 \mathrm{c}$ & $273 \mathrm{e}$ \\
\hline P. irregulare $\mathrm{C} 4953$ & $52.1 \mathrm{bc}$ & $69.8 \mathrm{bc}$ & $54.2 \mathrm{~b}$ & $69.2 \mathrm{~d}$ & $142 \mathrm{a}$ & $335 \mathrm{a}$ & $79 \mathrm{a}$ & $164 \mathrm{a}$ \\
\hline P. irregulare & $40.1 \mathrm{a}$ & $57.3 \mathrm{a}$ & $35.8 \mathrm{a}$ & $50.8 \mathrm{~b}$ & $154 \mathrm{ab}$ & $431 \mathrm{~b}$ & $101 \mathrm{ab}$ & $203 \mathrm{~b}$ \\
\hline P. conidiophorum & $45.8 \mathrm{~b}$ & $58.3 \mathrm{a}$ & $35.0 \mathrm{a}$ & $50.0 \mathrm{~b}$ & $248 \mathrm{c}$ & $525 \mathrm{c}$ & $127 \mathrm{~b}$ & $211 \mathrm{bc}$ \\
\hline$P$. intermedium & $75.0 \mathrm{~d}$ & $75.0 \mathrm{c}$ & $59.2 \mathrm{~b}$ & $65.8 \mathrm{~d}$ & $216 b c$ & $451 \mathrm{bc}$ & $172 \mathrm{c}$ & $214 \mathrm{bc}$ \\
\hline P. lutarium & $46.8 \mathrm{~b}$ & $52.8 \mathrm{a}$ & $31.7 \mathrm{a}$ & $30.8 \mathrm{a}$ & $265 \mathrm{c}$ & $488 \mathrm{bc}$ & $170 \mathrm{c}$ & $257 \mathrm{de}$ \\
\hline P. mamillatum & $56.2 \mathrm{c}$ & $65.6 \mathrm{~b}$ & $55.0 \mathrm{~b}$ & $59.2 \mathrm{c}$ & $223 \mathrm{c}$ & $438 \mathrm{~b}$ & $166 \mathrm{c}$ & $236 \mathrm{~cd}$ \\
\hline P. perplexum & 0 & 0 & 0 & 0 & $286 \mathrm{c}$ & $633 \mathrm{~d}$ & $158 \mathrm{c}$ & $267 \mathrm{e}$ \\
\hline Mean & 43.6 & 52.1 & 36.8 & 44.5 & 219 & 496 & 139 & 224 \\
\hline
\end{tabular}

${ }^{\mathrm{z}}$ Each experiment was arranged in a completely randomized design and repeated once with six replicate pots per treatment combination (two bean seeds/pot) planted; means within a column followed by the same letter do not differ significantly based on Fisher's least significant difference (LSD) at $P=0.05$. Results were pooled over the repeats of the experiment as described in the main text. Hypocotyl and root disease index were calculated as explained in the main text. 
mon Pythium sp. in Western Australia on diseased legumes $(10,11)$. In fact, of all the Pythium spp. tested, the historical P. irregulare isolate C4953 was most virulent in terms of reducing shoot and root dry weights.

Six of the eight Pythium spp. we identified have previously been isolated from common bean in other parts of the world. These included $P$. conidiophorum, $P$. diclinum, and $P$. pachycaule in Rwanda (32); P. irregulare and P. lutarium in Uganda (29); and $P$. mamillatum in Japan (24). In our study, $P$. intermedium-infected plants showed necrotic lesions on the both roots and hypocotyls, brown sunken cankers on taproots and on the hypocotyls, and decay of the secondary roots. Pre-emergence damping-off was also observed from this species and it was the most virulent isolate from our study. P. intermedium has been previously reported to be a pathogen causing root rot on coniferous species in north America (21) and on roses (Rosa spp.) in France (26), as well as a pathogen associated with root rot complex on parsnip (Pastinaca sativa), and parsley (Petroselinum crispum) in Australia (35). To the best of our knowledge, this is the first report of Pythium intermedium as a pathogen on common bean. The previous reports of $P$. intermedium causing significant root disease on other hosts suggest its potential to be a significant pathogen on common bean worldwide, and further evaluation of this is warranted.

$P$. conidiophorum, $P$. lutarium, and $P$. mamillatum are highlighted as pathogens of common bean in Australia for the first time in our study. $P$. conidiophorum was originally described as a pathogen on green algae (22), and reported to be associated with Pythium root disease on common bean in Rwanda (32). P. lutarium also has been isolated from common bean in Uganda (29). P. mamillatum has a wide host range and was originally isolated from beet (Beta vulgaris L.; 38). P. conidiophorum has been found in soils in South Australia (41) and also isolated from necrotic roots of subterranean clover (19). It is clear that P. conidiophorum, $P$. lutarium, and $P$. mamillatum have all been considered to be significant pathogenic species elsewhere and, for the first time, now need to be considered as pathogens capable of causing significant root and hypocotyl damage on common bean in Australia.

Two additional Pythium spp., P. pachycaule and P. diclinum, were also found to be pathogenic to common bean in our study. Although isolates of these two species could not be maintained in live culture for sufficient time to allow virulence tests for them to be conducted, further isolations of these species and virulence testing is warranted.

In summary, our study demonstrates that $P$. conidiophorum, $P$. diclinum, $P$. intermedium, $P$. irregulare, $P$. lutarium, $P$. mamillatum, and $P$. pachycaule can all cause root and hypocotyl disease on common bean. Our finding suggest that Pythium root and hypocotyl disease on common bean is likely more widespread and severe than previously assumed. The full extent of the impact of Pythium spp. on common bean production in Australia needs to be re-evaluated and defined through more extensive surveys to determine the occurrence of these Pythium spp. and the impact of the root and hypocotyl disease they cause on yield of dry and green bean production. Our finding that host resistance or susceptibility to one Pythium sp. was similar across the other species of this genus makes a significant contribution to the global breeding programs targeting development of new common bean varieties with improved resistance to Pythium root and hypocotyl disease. Based on our findings, once a resistant variety is identified, it potentially could be grown productively whatever the particular Pythium sp. or Pythium spp. combinations present, potentially allowing wider control of Pythium root and hypocotyl disease through improved host resistance across the major common bean growing regions of the world.

\section{Acknowledgments}

We thank the University of Western Australia International Postgraduate Research Scholarship for financial assistance to Y. P. Li; the School of Plant Biology for providing operational funding support for this research; C. Wood, V. Lanoiselet, and N. Eyres for the Australian Plant Pest Database information searches in relation to disease records in Australia and for provision of an isolate from the Department of Agriculture and Food Western Australia Culture Collection; B. Piasini for assistance with field surveys; and R. Creasy for assistance with running these controlled environment studies.

\section{Literature Cited}

1. Abawi, G. S., Crosier, D. C., and Cobb, A. C. 1985. Root rot of snap beans in New York. N.Y. Food Life Sci. Bull. No. 110. New York State Experimental Station, Geneva.

2. Abawi, G. S., and Pastor-Carrales, M. A. 1990. Root rots of bean in Latin America and Africa: Diagnosis, research, methodologies and management strategies. CIAT Publ. No. 35. Cali, Colombia.

3. Abawi, G. S., and Widmer, T. L. 2000. Impact of soil health management practices on soilborne pathogens, nematodes and root diseases of vegetable crops. Appl. Soil Ecol. 15:37-47.

4. Ali-Shtayeh, M., and Saleh, A. F. 1999. Isolation of Pythium acanthicum, $P$. oligandrum, and P. periplocum from soil and evaluation of their mycoparasitic activity and biocontrol efficacy against selected phytopathogenic Pythium species. Mycopathologia 145:143-153.

5. Allen, D. J. 1995. An Annotated List of Diseases, Pathogens and Associated Fungi of the Common Bean (Phaseolus vulgaris) in Eastern and Southern Africa. Mycological Institute, CAB International, Wallingford, UK.

6. Australian Plant Pest Database. Plant Health Australia 2013. www.plant healthaustralia.com.au

7. Bala, K., Robideau, G. P., Desaulniers, N., de Cork, A. W. A. M., and Lévesque, C. A. 2010. Taxonomy, DNA barcoding and phylogeny of three new species of Pythium from Canada. Persoonia 25:22-31.

8. Barbetti, M. J., and MacNish, G. C. 1978. Root rot of subterranean clover in the irrigation areas of south-western Western Australia. Aust. J. Exp. Agric. Anim. Husb. 18:426-433.

9. Barbetti, M. J., Riley, I. T., You, M. P., Li, H., and Sivasithamparam, K 2006. The association of necrotrophic fungal pathogens and plant parasitic nematodes with the loss of productivity of annual medic-based pastures in Australia and options for their management. Australas. Plant Pathol. 35:691-706.

10. Barbetti, M. J., Sivasithamparam, K., and Wong, D. H. 1986. Root rot of subterranean clover. Rev. Plant Pathol. 85:287-295.

11. Barbetti, M. J., You, M. P., Li, H., Ma, X., and Sivasithamparam, K. 2007. Management of root diseases of annual pasture legumes in Mediterranean ecosystems-a case study of subterranean clover root diseases in the southwest of Western Australia. Phytopathol. Mediterr. 46:239-258.

12. Bartels, D., and Sunkar, R. 2005. Drought and salt tolerance in plants. Crit. Rev. Plant Sci. 24:23-58.

13. Broughton, W. J., Hernández, G., Blair, M., Beebe, S., Gepts, P., and Vanderleyden, J. 2003. Beans (Phaseolus spp.)—model food legumes. Plant Soil 252:55-128.

14. Cenis, J. L. 1992. Rapid extraction of fungal DNA for PCR amplification. Nucleic Acids Res. 20:2380.

15. Central High Plains Dry Bean and Beet Group. 2004. Dry Bean Production \& Integrated Pest Management, 2nd ed. H. F. Schwartz, M. A. Brick, R. M. Harveson, and G. D. Frank, eds. American Phytopathological Society, St. Paul, MN.

16. Chambers, S. C. 1959. A revised list of vegetable diseases recorded in Western Australia. J. Agric. West. Aust. 8:427-431.

17. de Cock, A. W. A. M., Lévesque, C. A., Melero-vara, J. M., Serrano, Y., Guirado, M. L., and Gómez, J. 2008. Pythium solare sp. nov., a new pathogen of green beans in Spain. Mycol. Res. 112:1115-1121.

18. FAOSTAT. 2013. FAO Stat Statistical Database. Food and Agricultural Organization of the United Nations.

19. Greenhalgh, F. C., and Lucas, S. E. 1984. Effect of soil pasteurization on damping-off and root rot of subterranean clover caused by Fusarium avenaceum and Pythium spp. Soil Biol. Biochem. 16:87-88.

20. Harter, L. L., and Whitney, W. A. 1927. A transit disease of snap beans caused by Pythium aphanidermatum. J. Agric. Res. 34:443-447.

21. Hocking, D. 1970. Pythium intermedium, a newly recognized pathogen of coniferous seedlings in Canada. Can. Plant Dis. Surv. 50:121-123.

22. Jok1, M. 1918. Pythium conidiophorum nov. sp., ein parasit von spirogyra. Osterr. Bot. Z. 67:33-37.

23. Keane, P., and Brown, J. 1997. Disease management: Resistant cultivars. Pages 405-426 in: Plant Pathogens and Plant Diseases. J. F. Brown and H. J. Ogle, eds. University of New England, Armidale, Australia.

24. Matoba, Y., Kondo, N., Akino, S., Kodama, F., Naito, S., and Ebe, S. 2008. Identification and pathogenicity of Pythium species causing damping-off of kidney bean. Jpn. J. Plant Pathol. 74:81-85.

25. McKinney, H. H. 1923. Influence of soil temperature and moisture on infection of wheat seedlings by Helminthosporium sativum. J. Agric. Res. 26:195-218.

26. Metzger, R., Belbahri, L., Calmin, G., Badin, N., and Lefort, F. 2007. First report of Pythium intermedium causing root rot on Rosa canina rootstock in France. Plant Dis. 91:1055-1055.

27. Miklas, P. N., Kelly, J. D., Beebe, S. E., and Blair, M. W. 2006. Common bean breeding for resistance against biotic and abiotic stress: From classical to MAS breeding. Euphytica 147:105-131.

28. Miller, S. A., Riedel, R. M., and Rowe, R. C. 2012. Damping-off and root 
rot of beans. Ohio State Univ. Ext. Fact Sheet No. HYG-3110-95. Columbus.

29. Mukalazi, J. 2004. Pathogen variation and quantification of Pythium spp. in bean fields in Uganda. Ph.D. thesis, Makerere University, Kampala, Uganda.

30. Mwanza, E. J. M., and Kellas, J. D. 1987. Identification of the fungi associated with damping-off in the regeneration of Eucalyptus obliqua and $E$. radiata in a central Victorian forest. Eur. J. Plant Pathol. 17:237-245.

31. Nderitu, J. H., Buruchara, R. A., and Ampofo, J. K. O. 1997. Relationships between bean stem maggot, bean root rots and soil fertility: Literature review with emphasis on research in eastern and central Africa. African Highlands Initiative Technical Report Series No. 4, African Highlands Initiative, Nairobi, Kenya.

32. Nzungize, J., Gepts, P., Buruchara, R., Buah, S., Ragama, P., Busogoro, J. P., and Baudoin, J. P. 2011. Pathogenic and molecular characterization of Pythium species inducing root rot symptoms of common bean in Rwanda. Afr. J. Microbiol. Res. 5:1169-1181.

33. Nzungize, J., Gepts, P., Buruchara, R., Male, A., Ragama, P., Busogoro, J. P., and Baudoin, J. P. 2011. Introgression of Pythium root tot resistance gene into Rwandan susceptible common bean cultivars. Afr. J. Plant Sci. 5:193-200.

34. Otsyula, R. M., Buruchara, R. A., Mahuku, G., and Rubaihayo, P. 2003. Inheritance and transfer of root rots (Pythium) resistance to bean genotypes. Afr. Crop Sci. Soc. 6:295-298.

35. Petkowski, J. E., Boer, R. F., Norng, S., Thomson, F., and Minchinton, E. J. 2013. Pythium species associated with root rot complex in winter-grown parsnip and parsley crops in south eastern Australia. Australas. Plant Pathol. 42:403-411.

36. Pfender, W. F., and Hagedorn, D. J. 1982. Comparative virulence of Aphanomyces euteiches f. sp. phaseoli and Pythium ultimum on Phaseolus vulgaris at naturally occurring inoculum levels. Phytopathology 72:1200-1204.

37. Pieczarka, D. J., and Abawi, G. S. 1978. Populations and biology of
Pythium species associated with snap bean roots and soils in New York. Phytopathology 68:409-416.

38. Plaats-Niterinck, J. V. 1981. Monograph of the Genus Pythium. Studies in Mycology, No. 21. Centraalbureau voor Schimmelcultures, Baarn, The Netherlands.

39. Rusuku, G., Buruchara, R. A., Gatabazi, M., and Pastor-Carrales, M. A 1997. Occurrence and distribution in Rwanda of soilborne fungi, pathogenic to common bean. Plant Dis. 81:445-449.

40. Shivas, R. G. 1989. Fungal and bacterial diseases of plants in Western Australia. J. R. Soc. West. Aust. 72:1-62.

41. Vaartaja, O., and Bumbieris, M. 1964. Abundance of Pythium species in nursery soils in South Australia. Aust. J. Biol. Sci. 17:436-445.

42. White, T. J., Bruns, T., Lee, S., and Taylor, J. 1990. Pages 315-322 in: Amplification and Direct Sequencing of Fungal Ribosomal RNA Genes for Phylogenetics. Academic Press, San Diego, CA.

43. Wortmann, C. S., Kirkby, R. A., Aledu, C. A., and Allen, D. J. 1998. Atlas of Common Bean (Phaseolus vulgaris L) Production in Africa. Centro International de Agricultura Tropica, Cali, Colombia.

44. York, D. W., Dickson, M. H., and Abawi, G. S. 1977. Inheritance of resistance to seed decay and pre-emergence damping-off in snap beans caused by Pythium ultimum. Plant Dis. Rep. 61:285-289.

45. You, M. P., Barbetti, M. J., and Nichols, P. G. H. 2005. New sources of resistance identified in Trifolium subterraneum breeding lines and cultivars to root rot caused by Fusarium avenaceum and Pythium irregulare and their relationship to seedling survival. Australas. Plant Pathol. 34:237-244.

46. You, M. P., Sivasithamparam, K., Riley, I. T., and Barbetti, M. J. 2000 The occurrence of root-infecting fungi and parasitic nematodes in annual Medicago spp. in Western Australian pastures. Aust. J. Agric. Res 51:435-444.

47. Zaumeyer, W. J., and Thomas, H. R. 1957. A monographic study of bean diseases and methods for their control. Pages 65-74 in: U. S. Tech. Bull. U. S. Dep. Agric. No. 868. Washington, DC. 